\title{
Knowledge synthesis and translation in global food and nutrition security to evaluate and accelerate priority actions
}

\author{
Jørgen Torgerstuen Johnsen (D) , ${ }^{1}$ Luke Buckner, ${ }^{1}$ Sumantra Ray ${ }^{1,2,3}$
}

As highlighted in the global nutrition report (GNR) 2020, amidst the COVID-19 pandemic, there is increasing emphasis on the central role of nutrition in health and well-being. ${ }^{1}$ As the pandemic has challenged our food and health systems, the necessary measures to contain the spread of the disease have impacted and tested the food supply and agriculture sector. In the long term, if we fail to act, there will be untold impacts on food security, nutrition and the livelihoods of farmers, fishers and other workers in the food supply chain. Furthermore, the impact will be felt even harder in food security 'hot spots', including fragile and conflict-affected states, countries affected by multiple crises, the marginalised and vulnerable as well as countries with significant currency depreciation. ${ }^{23}$ The United Nations (UN) World Food Programme has warned that an estimated 265 million people could face food insecurity by the end of 2020, up from an estimated number of 135 million people before the crisis. ${ }^{4}$ However, while the pandemic poses serious challenges for the food security in the short term, it provides a unique opportunity to transform the food and agriculture sector in the long term to establish resilient food systems to face future shocks and challenges, including climate change. ${ }^{1}$

For decades, it has been reported that the number of people globally suffering from hunger is declining. Sadly, even

\footnotetext{
${ }^{1}$ NNEdPro Global Centre for Nutrition and Health, St John's Innovation Centre, Cambridge, UK

${ }^{2}$ School of Biomedical Sciences, Ulster University at Coleraine, Coleraine, UK

${ }^{3}$ School of Humanities and Social Sciences, University of Cambridge, Cambridge, UK
}

Correspondence to Professor Sumantra Ray, NNEdPro Global Centre for Nutrition and Health, StJohn's Innovation Centre, Cambridge CB4 OWS, UK; s.ray@nnedpro.org.uk before the pandemic, this was no longer true, with over 820 million people now having too little to eat as described in the 2019 report 'The State of Food Security and Nutrition in the World'. Unfortunately, we also continue to note an ever-rising epidemic of obesity and overnutrition worldwide, which makes ending hunger, and all forms of malnutrition by 2030 an immense challenge. However, with real political commitment, bolder actions and the right investments, reaching this vital Sustainable Development Goal (SDGs) remains achievable.

The UN 'Decade of Action on Nutrition (2016-2025)' (Nutrition Decade) is a commitment by UN Member States to undertake 10 years of sustained and coherent implementation of policies, programmes and increased investments to eliminate malnutrition in all its forms, everywhere, leaving no one behind. ${ }^{6}$ We are now at the midpoint of the Nutrition Decade, and the Food and Agricultural Organization as well as the World Health Organization are preparing for convening an open and inclusive dialogue for the midterm review. Meanwhile, the UN Decade of Family Farming (2019-2028) aims to shed new light on what it means to be a family farmer in a rapidly changing world, highlighting more than ever, the important role small-scale farmers play in eradicating hunger and shaping the future of our food. ${ }^{7}$ Family farming offers unique opportunities to ensure food security while improving livelihoods, better managing natural resources, protecting the environment and achieving sustainable development, particularly in rural areas. Thanks to their wisdom and care for the earth, family farmers are the agents of change we need to achieve SDG 2: Zero Hunger, a more balanced and resilient planet. ${ }^{7}$
With just 10 years to go, an ambitious global effort is underway to deliver the 2030 promise. The UN Secretary General called on all sectors of society to transform our world over 2020-2030. ${ }^{8}$ It tries to achieve this through the mobilisation of governments, civil society, businesses as well as calling on all to accelerate sustainable solutions. Today, progress is being made in many places but, overall, action to meet the goals is not yet advancing at the speed or scale required. It can be seen that 2020 must usher in a decade of ambitious actions to deliver the goals by 2030 through accelerating sustainable solutions to all the world's biggest challengesranging from poverty to climate change, inequality and closing the finance gap.

To quote Gerda Verburg, coordinator of the 'Scaling Up Nutrition Movement', 'After this crisis (COVID-19), nutrition must be understood and recognised as an indispensable part of health, food, education and economic development'. With the requirement for all to play a part in maintaining momentum to drive these promises forward and learn from recent events, the scientific community must be encouraged to continue synthesising and translating knowledge into action. We hope that through a collection of inter-related articles in this field, we will be able to collate evidence and insights addressing global priorities in food and nutrition security. This will include methods of tackling current issues, in light of the three UN decades and the COVID-19 pandemic, as well as evaluation of equitable food production and distribution in the spirit of nutrition and well-being for all, as outlined in the 2020 GNR as well as associated global research translation initiatives. ${ }^{1}$

The GNR proposes these key actions:

- Invest in nutrition, particularly in communities disproportionately affected by the double burden of malnutrition.

- Build equitable, resilient and more sustainable food and health systems.

- Focus on collaborative efforts; this is vital to overcoming barriers to progress to end malnutrition.

- Leverage key moments to revitalise and expand nutrition 
commitments as well as strengthen accountability for these.

We propose an additional focus on these key areas:

- Capacity building in nutrition education, action research and the health workforce.

- Embedding data-driven risk assessment and risk management into food and health systems.

Contributors JTJ and LB drafted the editorial. SR supervised, reviewed and suggested the structure of the editorial. All authors reviewed and edited the final revision.

Funding The authors have not declared a specific grant for this research from any funding agency in the public, commercial or not-for-profit sectors.

Competing interests None declared.

Patient consent for publication Not required.

Provenance and peer review Commissioned; internally peer reviewed.

\section{(2) OPEN ACCESS}

Open Access This is an open access article distributed in accordance with the Creative Commons
Attribution Non Commercial (CC BY-NC 4.0) license, which permits others to distribute, remix, adapt, build upon this work non-commercially, and license their derivative works on different terms, provided the original work is properly cited, appropriate credit is given, any changes made indicated, and the use is non-commercial. See: http://creativecommons.org/ licenses/by-nc/4.0/.

C Author(s) (or their employer(s)) 2020. Re-use permitted under CC BY-NC. No commercial re-use. See rights and permissions. Published by BMJ.

\section{(D) Check for updates}

To cite Johnsen JT, Buckner L, Ray S. Knowledge synthesis and translation in global food and nutrition security to evaluate and accelerate priority actions. BMJ Nutrition, Prevention \& Health 2020;3:e000104. doi:10.1136/bmjnph-2020-000104

Received 19 May 2020

Accepted 21 May 2020

Published Online First 10 June 2020

bmjnph 2020;3:e000104.

doi:10.1136/bmjnph-2020-000104

ORCID iD

Jørgen Torgerstuen Johnsen http://orcid.org/

0000-0001-8041-9968

\section{REFERENCES}

1 Global Nutrition Report. Action on equity to end malnutrition [Internet]. Bristol, UK, 2020.
Available: https://globalnutritionreport.org/ reports/2020-global-nutrition-report/

2 OECD. COVID-19 and the Food and Agriculture Sector: Issues and Policy Response [Internet], 2020. Available: https:// read. oecd-ilibrary.org/view/?ref $=130$ 130816-9uut45lj4q\&title=Covid-19-and-thefood-and-agriculture-sector-Issues-andpolicy-responses\&utm_source=Adestra\& utm medium=email\&utm content=Read the brief\&utm_campaign=Agriculture COVID blast\&utm term $=$ demo

3 The World Bank. Food Security and COVID-19 [Internet], 2020. Available: https://www.worldbank.org/en/topic/ agriculture/brief/food-security-and-covid19

4 Anthem P. Risk of hunger pandemic as COVID-19 set to almost double acute hunger by end of 2020 [Internet]. World Food Programme Insight, 2020. Available: https:// insight.wfp.org/covid-19-will-almost-doublepeople-in-acute-hunger-by-end-of-202059df0c4a8072

5 The State of Food Security and Nutrition in the World 2019. The State of Food Security and Nutrition in the World 2019 [Internet], 2019. Available: http://www.fao.org/3/ ca5162en/ca5162en.pdf

6 United Nations. United Nations Decade of Action on Nutrition 2016-2025 [Internet]. Available: https://www.un.org/nutrition/

7 FAO, IFAD. United Nations Decade of Family Farming 2019-2028 Global Action Plan [Internet], 2019. Available: http://www.wipo. int/amc/en/mediation/rules

8 United Nations. Decade of Action - United Nations Sustainable Development [Internet], 2020. Available: https://www.un.org/sustaina bledevelopment/decade-of-action/ 